\title{
Reframing New Zealand's Biosecurity Conversation Post-Covid-19: An Argument for Integrating Interspecies Concerns
}

Author: Deidre Ann McDonald

To cite this article: McDonald, D. A. (2020). Reframing New Zealand's Biosecurity Conversation Post-Covid-19: An Argument for Integrating Interspecies Concerns. National Security Journal, 3(1). doi:10.36878/nsj20200202.07

To link to this article: https://doi.org/10.36878/nsj20200202.07

View CrossRef data: https://search.crossref.org/?q=10.36878\%2Fnsj20200202.07 


\title{
REFRAMING NEW ZEALAND'S BIOSECURITY CONVERSATION POST-COVID-19: AN ARGUMENT FOR INTEGRATING INTERSPECIES CONCERNS
}

\author{
Deidre Ann McDonald ${ }^{1}$
}

\begin{abstract}
This article began in March 2020, during New Zealand's Alert Level 4 lockdown, and the writing process has spanned more than five months of the SARS-CoV-2 (COVID-19) pandemic. As at August 2020, COVID-19 continues to rage across the globe, while New Zealanders enjoy a relative freedom of movement. Due to a collective commitment to biosecurity practices such as isolation, quarantine and movement restrictions, along with the government's strong public health messaging, the 'team of five million' had, at the time of writing, eliminated COVID-19 from our communities. This article discusses New Zealand's biosecurity messaging in light of COVID-19, and argues that biosecurity discussions that link animal management practices with risks to human health are essential for pandemic preparedness. As a global leader in biosecurity, New Zealand is well placed to make the conceptual shift towards treating public health and biosecurity as a shared concern.
\end{abstract}

Keywords: Biosecurity, COVID-19, human health, national security, New Zealand.

\section{Introduction}

The SARS-CoV-2 (COVID-19) pandemic was not a 'black swan' event. ${ }^{1}$ The World Health Organisation (WHO) has been warning us about the rise of a novel influenza of pandemic proportions for years. ${ }^{2}$ Despite the work of WHO, the Food and Agriculture Organisation of the United Nations (FAO) and the World Organisation for Animal Health (OIE) promoting awareness of risks to public health arising from human/animal relationships, the world was still collectively unprepared for COVID-19. ${ }^{3}$ Even in New

$1 \quad$ Deidre McDonald is a Teaching Fellow at the Centre for Defence and Security Studies, School of People, Environment and Planning, at Massey University, Manawatū. Contact by email d.mcdonald@ massey.ac.nz. Thank you to my anonymous peer-reviewers and the journal's Managing Editor for their helpful feedback, all of which has resulted in a different and infinitely better product. 
Zealand, a country that is credited with having the most comprehensive biosecurity system in the world, ${ }^{4}$ our biosecurity messaging tends to treat public health and biosecurity as separate concerns. Yet, we know that for biosecurity to succeed in securing human, animal and plant health, community engagement and awareness are required from all sectors of society. ${ }^{5} \mathrm{~A}$ biosecurity narrative that links food handling and animal processing practices with animal biosecurity management and risks to human health is essential for preparedness for future epidemics and pandemics.

Up until the 11 August announcement of renewed Alert Level 3 restrictions in Auckland, New Zealand's pandemic response had been successful in eliminating ${ }^{2}$ COVID-19, and the public health messaging was clear and strong, ${ }^{6}$ but it still conceptualised human health practices in ways that invisibilise the relationship between human and animal health; certainly, there were no express links made between pandemic management practices and (the more commonly understood) food safety and animal biosecurity practices. ${ }^{7}$ COVID-19 has highlighted the direct connection between human and animal health, and this is an opportunity for New Zealand to re-examine its national biosecurity conversation and to rebuild an integrated narrative for the future.

New Zealand has not had an influenza outbreak of COVID-19 proportions in over 100 years, ${ }^{8}$ which could explain why contagious human diseases are the least well traversed of our biosecurity objectives. Nonetheless, human health has remained largely absent from our society's biosecurity consciousness, even though biosecurity is concerned with human health as well as economic, environmental and social security. ${ }^{9}$ Human health in the biosecurity context is usually discussed with reference to food-borne illnesses such as campylobacter, or high-profile food safety issues such as the whey-protein concentrate incident of 2013 (WPC80 Incident). ${ }^{10}$ The WPC80 Incident involved the suspected contamination of thirty-eight tonnes of whey-protein concentrate, which is an ingredient in some infant formulas, with clostridium botulinum - the bacteria causing botulism. ${ }^{11}$

Even New Zealand's National Security System Handbook (2016) (Security System Handbook) expressly lists "biosecurity events and pandemics"12 as separate entries, though perhaps the distinction in this document simply reflects that the Ministry of Health $(\mathrm{MoH})$ takes the lead on pandemic management, as opposed to the Ministry for Primary Industries (MPI). ${ }^{13}$ Despite this, the New Zealand Influenza Pandemic Plan: A Framework for Action (New Zealand Pandemic Plan) does state that where humans

2 The goal of elimination is to break community transmission of COVID-19 and limit any new cases to either zero (best case) or a very low target number (next best case) in a defined geographical location. Elimination contemplates some new cases of the disease, whereas eradication means that there are no existing or new cases of the disease in the country. Eradication is not a viable option for COVID-19 while the virus remains in global circulation without any vaccination options. See Aotearoa/New Zealand's COVID-19 Elimination Strategy: An Overview (Wellington: Ministry of Health, 2020), https://www. health.govt.nz/system/files/documents/pages/aotearoa-new_zealands_covid 19_elimination_strategy-_ an_overview17may.pdf. 
contract diseases directly from handling infected animals, then MPI is the lead agency. ${ }^{14}$ There are two key themes running through this article. The first is that COVID-19 has highlighted that our national biosecurity conversation tends to exclude interspecies health risks and the implications of these for securing all other areas of life. Secondly, human health security is bound up with animal health and biosecurity, including food safety, and it should be discussed in an interspecies context.

This article is written in two parts. The first part sets out the meaning of biosecurity and the purpose of its practices, relying on academic literature as well as New Zealand's own public policy definition of the term. This part also explores the importance of 'contexts' for biosecurity management practices. Next, the article discusses the thorny issue of biological insecurity between humans and animals, with a particular focus on zoonotic diseases (those that transmit from animals to humans) of pandemic proportions. ${ }^{15}$ The second part of the article unpacks New Zealand's biosecurity narrative by exploring some key public messaging related to biosecurity's four stated objectives of environmental, economic, social and cultural and human health security. Part two then argues for a greater integration of human health into our national biosecurity conversation. The article finishes with some concluding remarks about the opportunity for new biosecurity understandings arising from the recent 'white swan' COVID-19 pandemic. $^{16}$

\section{PART I}

\section{Biosecurity}

Biosecurity is a discipline consisting of a range of situated practices ${ }^{17}$ that are carried out for the purpose of protecting valued and valuable life. ${ }^{18}$ Clark (2013) colourfully describes biosecurity as an "attempt to protect established and valued life from emergent, transgressive and undesirable life." ${ }^{19}$ Biosecurity is essentially concerned with how humans manage other species and organisms for our environmental, economic and/or social benefit - including protecting human health. ${ }^{20}$ Hinchliffe and Bingham (2008) use the verb 'biosecuring' to highlight what they call an "unfinished business" ${ }^{21}$ of securing wanted biological life from unwanted organisms. Collier, Lakoff and Rabinow (2004) describe biosecurity's ongoing and situated practices as "site[s] of problematisation". ${ }^{22}$ These sites of problematisation manifest in places such as farms, orchards, nature reserves, government departments, scientific laboratories and even the backyards of Grey Lynn residents. ${ }^{23}$ Braun (2008) reminds us that wherever biosecurity is practiced these sites will always involve human and non-human elements. Braun calls these biosecurity sites "more than 'social" ${ }^{4}$ because humans, animals, plants, insects, bacteria and viruses continually interact to create mutable contexts for biosecurity actions. $^{25}$ 
Barker (2013) observes that there are three main categories of interspecies relations that attract biosecurity intervention (e.g., the practices of exclusion, eradication or management). These categories are:

1. Pests and diseases affecting indigenous flora and fauna. New Zealand examples in this category include kauri dieback and myrtle rust diseases.

2. Communicable diseases impacting on human health, such as measles and COVID-19.

3. Diseases compromising economic security, often relating to the primary sector. New Zealand examples in this category include the cattle disease mycoplasma bovis (M. bovis) and the kiwifruit disease pseudomonas syringae pv. actinidiae. ${ }^{26}$

As is clear from the examples above, New Zealand has either dealt with or is currently dealing with problematic life in each of Barker's three biosecurity categories. However, as will be seen, New Zealand's biosecurity narrative primarily focusses on economic safety from agricultural and horticultural pests and diseases, and the category of environmental protection. COVID-19 provides us with an opportunity to start having a different kind of biosecurity conversation - one in which the risks associated with, and implications arising from, animal-human connections are openly discussed and evaluated in all New Zealand communities. The world needs to be better prepared for the next pandemic, and given that most communicable diseases of pandemic proportions are zoonotic, discussing interspecies relations is a biosecurity imperative. ${ }^{27}$

\section{Human and animal diseases}

Disease is prevented, prepared for and managed in more than social sites of biosecurity for healthy human and animal outcomes. Harris Ali and Keil (2008) argue that viruses are capable of 'folding' space and time, because of the ways in which they can seemingly transmit across countries' borders in non-linear ways. ${ }^{28}$ Here we see nature's adaptability in the context of not only the more than social, but the global, where time and space are no longer separate entities, and where 'time-space' cannot be relied on to perform in a straight-forward manner. ${ }^{29} \mathrm{~A}$ globally connected world means that temporal and spatial tracing techniques alone have become unreliable measures of safety from the spread of infectious diseases, so our concepts of proximity and distance need to be framed as non-linear flows and folds. ${ }^{30}$ To assist with this reframing, Hinchliffe et al., (2013) imagine disease as continuously absent and present, as opposed to being part of a binary system of alternatively absent or present. ${ }^{31}$ If we consider biosecurity risk in this nonbinary light, we can see how the health/disease of species of all kinds is continuously and contemporaneously folded together, cohabiting at sites of problematisation. ${ }^{32}$

Hinchliffe et al., (2013) observe that agricultural biosecurity still predominantly concerns itself with the statistical 'mapping' or spatio-temporal 'tracing' of populations the management of disease being based largely on past events and movements, which 
then becomes the basis for future predictions. ${ }^{33}$ Yet, practices of exclusion that have worked well in the past, for example to eradicate leprosy or contain small-pox, may not work equally well in the case of an advanced influenza pandemic. We need to allow space for each complex matrix of health/disease to 'speak' ${ }^{34}$ because incursions and outbreaks provide an opportunity to better understand the nature of emergence. ${ }^{35}$

Each human body is situated within and influenced by a network of other organisms, including diseases that can transmit from animals (including malaria and dengue fever from insects) to humans ${ }^{36}$ Global pandemics such as COVID-19, the H5N1 virus (avian flu) and Severe Acute Respiratory Syndrome (SARS) each demonstrate that individual bodies are part of and are affected by biological networks. ${ }^{37}$ These networks consist of humans, animals, markets, viruses, transport, hotels and workplaces. ${ }^{38}$ Braun says that while it may seem strange to conceptualise human and animal bodies as interconnected, it makes perfect sense in the context of the folds of disease in pandemics. In the case of SARS, for example, some of these situational networks included live animal markets, hotels, aeroplanes, hospitals, Toronto's city streets, and its busy cafes. ${ }^{39}$ Somewhat paradoxically, the hotspots of disease spread are close connections as well as divergent movements. An agricultural example of the interspecies nature of biosecurity is New Zealand's M. bovis outbreak. Mycoplasma bovis demonstrates that cattle are part of a biological network consisting of other cattle, humans, science, veterinary medicines, meat-works, milking machines and the M. bovis bacterium itself. ${ }^{40}$ These are all sites of problematisation, and for disease management purposes it is important to remember that each animal and human body exists in this space and in this time and under these conditions. ${ }^{41}$

The issue of how humans interact with and relate to animals may well be one of the biggest security challenges we face in the twenty-first century. ${ }^{42}$ Clark (2013) says that the transformative power of unwanted biological life such as pests, bacteria and viruses has emerged in recent times as a global political issue. ${ }^{43}$ Yet, perhaps our risks have not necessarily increased with respect to zoonotic diseases: we have always lived with animals, whether they be wild, farmed or domesticated:

[Animals] have continuously circulated through [social] spaces, in the form of dairy products, meats, clothing, even pharmaceuticals, not to mention waste and viscera. They have surrounded us as house pets, rodents, birds, foxes, and feral cats. And they have formed complex humananimal assemblages, at times aided by insects, viruses, and bacteria that trace lines of connection between them all. ${ }^{44}$

The modern twist is that humans have created complex, time-sensitive supply chains, making all humans and animals 'touch' more than ever before, and this virtually ensures that novel transmissible diseases can multiply on an exponential basis. ${ }^{45} \mathrm{One}$ obvious challenge for securing biological life of all kinds has always been how to support 
valued and valuable life's mobility while removing, halting or preventing threats to its thriving. ${ }^{46}$ As Hinchliffe (2013) observes, "the trouble is that good and bad often share the same spaces." ${ }^{47}$

Post-COVID-19, the second of Barker's biosecurity categories (communicable diseases impacting on human health) will likely loom large over our biosecurity practices in all of their manifestations from now on. For example, there might be changes in the use and status of 'biosecurity control areas' ${ }^{48}$ at airports to routinely incorporate human disease testing, or proof of immunity/vaccination certification could be required for all travellers in the future. ${ }^{49}$ We may see calls for ongoing compulsory quarantine or isolation for people and goods, slowing down human and trade movements between countries or regions. There will doubtless be implications for biosecurity practices relating to farmed animals and primary products, too, which are commodities that are vital to New Zealand's economic security - along with the movement of people.

\section{PART II}

\section{Biosecurity in New Zealand}

New Zealand's definition of biosecurity is set out in a high-level strategic document titled the Biosecurity 2025 Direction Statement for New Zealand's Biosecurity System (Biosecurity 2025). Biosecurity 2025 defines biosecurity as "the exclusion, eradication or management of pests and diseases that pose a risk to the economy, environment, cultural and social values, including human health." ${ }^{50}$ Unsurprisingly, this policy definition has been drafted around biosecurity practices, or the ongoing attempts to make valued life more secure. The practice of exclusion refers to keeping pests and diseases off-shore, while eradication refers to removing those pests and diseases from New Zealand, and management generally refers to long-term management where exclusion and eradication have not been possible. ${ }^{51}$ The four areas of New Zealand society that biosecurity attempts to make secure are the economy, the environment, human cultural and social values, and human health. The Biosecurity 2025 Workplan: Strategic Direction 5 Tomorrow's skills and assets (Biosecurity 2025 Workplan) clearly sets out the importance of "[i]ncreased awareness and informed connections between all components of the [biosecurity] system...including recognition of the impacts and benefits of the system on human health." ${ }^{52}$ These documents expressly contemplate biosecurity conversations that include reference to zoonotic diseases and animalhuman connections and relationships.

There is a previous definition of biosecurity that was set out in Tiakina Aotearoa/Protect New Zealand: The Biosecurity Strategy for New Zealand (Biosecurity Strategy), which was the predecessor to the current Biosecurity 2025. The Biosecurity Strategy was published in 2003, but even then biosecurity was defined with express reference to human health: "[b]iosecurity is the exclusion, eradication or effective management of risks posed by 
pests and diseases to the economy, environment and human health." ${ }^{33}$ A quick comparison shows that the definition has evolved over time to include 'cultural and social values'.

New Zealand's biosecurity system developed largely as a result of the country's move to embrace tariff-free trade for agricultural products. ${ }^{54}$ The Biosecurity Act 1993 was consequently enacted to protect animal product exports, resulting in New Zealand becoming the first country in the world to use the term 'biosecurity' in relation to animal health. ${ }^{55}$ Trampusch (2014) observes that "[t]he government therefore armed the agricultural sector to benefit fully from consumer markets worldwide by protecting its agricultural producers from pests and diseases."56 Securing indigenous flora and fauna from biological harm (Barker's first biosecurity category) has been another key biosecurity priority for New Zealand. Biosecurity is concerned with the safety and security of the natural environment because of the ecosystem services that support the country's primary product exports and because the natural environment supports people's cultural and social values and their way of life. ${ }^{57}$ The protection of environmental and economic security is discussed in more depth below.

As mentioned earlier, biosecurity concerns falling into Barker's second category of communicable diseases impacting on human health have mostly presented in New Zealand as food safety and/or trade issues. New Zealand has been in an enviable position where national biosecurity issues have not needed to focus on zoonotic diseases or human pandemics. COVID-19, being both zoonotic and able to spread easily from human to human, should mark a significant shift in the way biosecurity is understood and discussed by New Zealanders from now on. Before turning to explore some of the implications of COVID-19 for New Zealand's biosecurity conversations, let us consider each of biosecurity's stated objectives. These four objectives inform us about localised sites of biosecurity in New Zealand, and help us to imagine the likely intersection of COVID-19 with all areas of biosecurity concern.

\section{Environmental and economic security}

Primary products (agricultural, horticultural, forestry and fishing) comprise over half of New Zealand's total exports. ${ }^{58}$ Primary sector exports earned New Zealand over NZ $\$ 46$ billion in the twelve months prior to June 2019, and prior to the COVID-19 pandemic this figure was forecast to reach nearly NZ $\$ 48$ billion by June $2020 .{ }^{59}$ As at December 2019, dairy export revenue alone was expected to reach NZ\$19.6 billion for the year ending June 2020, and meat and wool exports were forecast to reach NZ\$10.4 billion for the same period..$^{60}$ COVID-19 has caused significant trade and supply-chain disruption, which has highlighted the existing risks relating to exporting primary products. ${ }^{61}$ Unexpectedly, a recent Economic Update for the Primary Industries report shows that revenue from primary products exports is actually NZ $\$ 1.7$ billion higher than for the same period in 2019.62 However, these revenue gains are being buoyed 
by the falling New Zealand dollar, without which export revenue would have instead dropped by 1.2 percent. ${ }^{63}$ It remains to be seen what the international trade landscape will look like in twelve months from now, but MPI predicts that economic activity will take years to fully recover from COVID-19 due to a range of factors, including a change in consumer behaviours, social distancing requirements continuing in many countries and decreased airfreight capacity to transport high value, fresh products. ${ }^{64}$

In recent years, tourism had rivalled agricultural exports as an important economic contributor, with the tourist dollar exceeding the export value of dairy products in 2019. ${ }^{65}$ Before COVID-19, annual tourist numbers were predicted to increase to four and a half million by the year $2022 .{ }^{66}$ Now, however, our borders remain closed to travellers, Air New Zealand and other airlines have announced staff redundancies and have limited their flights, and most tourism operators are struggling to keep staff employed ${ }^{67}$ At the time of writing, there is no indication as to when non-New Zealand citizens or permanent residents will be able to return to this country. COVID-19's impact will continue to be harshly felt in all of the areas of biosecurity concern, not solely in the areas of human health and the national economy - although these impacts have been severe. ${ }^{68}$ New Zealand's reliance on tourism and the primary sector makes it particularly vulnerable when those flows suddenly dry up. ${ }^{69}$ A key biosecurity message must be that the smallest virus can be as deadly and destructive to the ways of life of people as are acts of traditional warfare in this more than social world.

Ironically, one of the growing pressures on New Zealand's natural environment has been the increasing number of international travellers, so there is perhaps a silver-lining for the environment at this time. ${ }^{70}$ The very border flows that sustain us economically also create additional environmental and human health risks. ${ }^{71}$ Conversely, stopping the human flows and disrupting trade creates its own set of economic, social and possibly environmental risks. The tourism levy, for example, has stopped with the flow of travellers, and this levy helps fund pest-control, breeding programmes, national parks and reserves. ${ }^{72}$ Biosecurity's objectives are linked by complex domino-like formations, which means that there will be consequences arising from insecurity in one area for the others, but we do not always know how the dominos are linked or in which direction they will fall.

\section{Cultural and social security}

Tassin and Kull (2015) consider cultural and social values to be "inextricable from the science and management of invasions"73 because how humans construct nature and the types of nature we collectively value are integral to biosecurity policy and practice. In New Zealand, both indigenous and/or exotic flora and fauna are valued - the former for its biodiversity, endemicity and cultural value for Māori, ${ }^{74}$ and the latter for economic imperatives. In New Zealand, we also know that not all accidentally introduced species are problematic for the biological security of indigenous and exotic flora and 
fauna. Williamson's (1996) 'tens rule', for example, highlights that one in ten introduced species will successfully escape into the wild, one out of ten that escape will become established, and one out of ten that become established will become a pest. ${ }^{75}$ Moreover, New Zealand's own definition of biosecurity acknowledges that only introduced life that poses a risk of harm is to be subjected to biosecurity management. Destructive biological behaviour cannot be conflated with the social construct of 'belonging', because a species' status as exotic or alien is no prediction of its invasive, or indeed of its beneficial, qualities. ${ }^{76}$

The 'belonging' line of inquiry becomes even more problematic when the geopolitical question inevitably arises as to what point in time human populations are considered to legitimately 'belong' in any place, including in New Zealand. ${ }^{77}$ Any xenophobia that might have existed previously around the world has been highlighted with the advent of COVID-19. In New Zealand, there have been reports of overt racism towards people of Asian lineage in public places as well as free-flowing nationalistic sentiments when it comes to closing the border to returning New Zealand citizens or residents with non-European heritage. ${ }^{78}$ This racial tension is also bound up with belonging; who and what is considered to belong is linked to a country's cultural and social values. Adding a pandemic into the equation, with its consequential economic hardship, social deprivation and restrictions on the freedom of movement brings societal issues of privilege and inequality to the fore.

There is a further cultural dimension of biosecurity that deserves a mention. New Zealand is a country with a strong hunting and fishing culture, and hunting wild animals exposes humans to any diseases that they may carry. Feral pigs and ducks, in particular, are known to carry diseases that can pass to humans. ${ }^{79}$ Moreover, New Zealand provides an important stop for migrating birds, which also carry diseases collected from other shores. ${ }^{80}$ All avian species, including poultry, harbour diseases that can spill over into humans through contact and/or food preparation practices. The New Zealand Pandemic Plan acknowledges this connection when it states that MPI's role in pandemic planning and response includes investigating sick animals, preparing technical information about animal influenzas, and creating import health standards as a preventative measure for influenza in imported animal material. ${ }^{81}$ However, our biosecurity conversations do not tend to include safe practices around zoonotic diseases and wild animals, even though this is a risk area for New Zealanders (as recognised by the Biosecurity 2025 Workplan) that requires community education and discussion.

\section{Human health security}

At the time of writing, more than 600,000 people world-wide have died from the COVID-19 virus, including 22 people in New Zealand. ${ }^{82}$ A vaccine for COVID-19 seems likely, but there remains uncertainty within the scientific community about the extent of any immunity conferred and how long that immunity would last in indi- 
viduals. ${ }^{83}$ The last time there was a pandemic of COVID-19 proportions was in 1918, which was an influenza outbreak that killed an estimated 50 million people world-wide, including 9,000 in New Zealand. ${ }^{84}$ This so-called 'great influenza' had zoonotic origins, though there remains uncertainty about the nature and number of animal hosts responsible for the 1918 outbreak. ${ }^{85}$ Other zoonotic diseases of note in the last twenty years include avian flu, the H1N1 virus (swine flu), SARS, Middle Eastern Respiratory Syndrome (MERS) and the Ebola Virus Disease (EVD) ${ }^{86}$ Each of these communicable diseases emerged from human-animal contact, whether it be in the food processing or animal husbandry context. ${ }^{87}$

The ever-present possibility of emerging diseases in farmed as well as wild animals, and the consequential movement of diseases between animals of the same species, across different species and between animals and humans, already directly affects the ways in which animal flows and connections are managed. ${ }^{88}$ Some examples of diseases in these categories that are actively excluded or managed with biosecurity practices include M. bovis, mycobacterium bovis (bovine TB), foot-and-mouth disease and bovine spongiform encephalopathy (mad cow disease). Yet, New Zealand's economic and social reliance on the health security of a hybrid ecological environment of farmed animals and indigenous species sets a rather unorthodox scene for the incorporation of a new and emerging biosecurity threat: transmissible diseases among humans capable of reaching pandemic proportions and originating in animals. COVID-19 has highlighted an 'absent/presence ${ }^{89}$ in our national biosecurity conversation of interspecies health risks and the implications of these for all other areas of biosecurity.

\section{Reframing New Zealand's biosecurity conversation}

In the New Zealand context, unwanted biological manifestations pose a continual challenge to the health and wellbeing of communities, the security of the environment and the country's economy..$^{90}$ Our biosecurity practices already negotiate the tension inherent in the co-existence of agriculture and conservation, both in terms of the biological vulnerabilities of large-scale animal and plant operations and the precariousness of biodiversity in our indigenous landscape. ${ }^{91}$ However, the COVID-19 pandemic has highlighted the need for New Zealand's biosecurity practices, such as the ability to extensively and quickly contact-trace in any type of biosecurity response, to continually demonstrate flexibility and responsiveness in the face of biological indeterminacy. ${ }^{92}$ Flexible and responsive biosecurity practices are essential if we are to pre-empt or even just keep up with life's mobility and mutability. ${ }^{93}$ The first step in learning COVID-19's valuable lessons is to change society's biosecurity lens to include an ever present threat of zoonotic diseases, and New Zealand is in a good position to be a global leader in having these discussions. 
Many of the biosecurity practices implemented in a plant or animal biosecurity response and public health practices implemented in a public health emergency are the same. ${ }^{94}$ The tools of surveillance and tracing, testing and monitoring, controlling or eradicating (in the case of animal diseases like $\mathrm{M}$. bovis) and containing or eliminating (in the case of human diseases like COVID-19), can all be used to manage animal, plant and human diseases. ${ }^{95}$ There are various sociological framings that underpin and explain the different biosecurity approaches, whether they involve exclusion of disease (elimination), containment of disease (isolation) or acceptance of disease within the population (vaccination and immunity). ${ }^{96}$ We have seen countries adopting one or more of these forms of management in the face of COVID-19's global emergence. To take a contrasting example, New Zealand has taken an extreme exclusion approach to disease management, while Sweden has taken an extreme herd immunity approach. ${ }^{97}$ New Zealand's initial lockdown was successful in eliminating community transmission of COVID-19, but being ahead of other countries means that the border must remain the critical point of exclusion until the pandemic ends. Sweden's decision to allow more individual freedoms and greater social mingling has resulted in a high number of deaths (more than 5,500), but if herd immunity is possible then Sweden is free to open up its borders to international workers, students and travellers more quickly than New Zealand. ${ }^{98}$ We have seen how COVID-19 requires high-stakes biosecurity decision-making, and countries' risk assessments are currently being made at the cutting edge of human disease management.

\section{The COVID-19 and M. Bovis responses}

In the world before COVID-19, New Zealand's Biosecurity Minister described M. bovis as the biggest biosecurity event the country had ever dealt with, which is a significant claim because the country has faced many pest and disease incursions over the years. ${ }^{99}$ An eradication approach was taken with M. bovis, with approximately 157,000 cattle having been culled to date (though to put this figure in context, there are approximately 10 million cattle in New Zealand). ${ }^{100}$ Scientific experts are optimistic that eradication remains achievable two years on from the biosecurity decision being made. ${ }^{101}$ COVID-19, on the other hand, has involved human as opposed to bovine quarantine and movement restrictions, and elimination of the disease is the goal, as opposed to eradication. Below is a table broadly comparing how each site of biosecurity has been managed and some of the peculiarities of each disease. The purpose of the below comparison is to illustrate the overlap between human and animal disease biosecurity practices, and the importance of localised disease contexts for management responses.

As can be seen from Figure 1, there are key similarities and differences between the M. bovis and COVID-19 responses. The similarities include: the two metre (social) distancing rule being recommended for humans in public places and individual cattle at calf-club days (see the biosecurity posters at Figure 2); standard biosecurity/hygiene 


\section{NATIONAL SECURITY JOURNAL}

practices being in place for both species; some humans/cattle will remain asymptomatic whilst infected; and there are no reliable vaccination options for either disease. There are also some important differences between the two diseases and their management: M. bovis is non-zoonotic, and COVID-19 originates in animals; cattle are likely to have M. bovis for life, whereas people may build up (limited) immunity to COVID-19; ${ }^{102}$ herd immunity is not possible for M. bovis, but it may be a possible strategy against COVID-19 through vaccination or recovery; and the goal is eradication for M. bovis (cattle are culled), yet the goal for COVID-19 is elimination (humans are ideally cured).

Figure 1: Comparative analysis between COVID-19 and M. bovis ${ }^{103}$

\begin{tabular}{|c|c|}
\hline COVID-19 & M. bovis \\
\hline Humans & Cattle \\
\hline Zoonotic & Non-zoonotic \\
\hline Newly emerging on global scale & Established globally, but new to New Zealand \\
\hline $\begin{array}{l}2 \text { metre social distancing between people from } \\
\text { different bubbles }\end{array}$ & $\begin{array}{l}2 \text { metre distance between animals from differ- } \\
\text { ent herds }\end{array}$ \\
\hline No vaccination available, but working on it & No vaccination available, not working on it \\
\hline $\begin{array}{l}\text { Symptoms range from mild to severe, some as- } \\
\text { ymptomatic }\end{array}$ & $\begin{array}{l}\text { Asymptomatic and symptomatic, but shedding } \\
\text { can occur at anytime }\end{array}$ \\
\hline Treating experimentally for serious cases & Treatment not effective \\
\hline Humans recover or die & Cattle likely to have M. bovis for life \\
\hline $\begin{array}{l}\text { Urged to adhere to good biosecurity practices } \\
\text { - new thinking for humans }\end{array}$ & $\begin{array}{l}\text { Urged to adhere to good biosecurity practices } \\
\text { - established thinking for animals }\end{array}$ \\
\hline Herd immunity may be possible & No herd immunity possible \\
\hline $\begin{array}{l}\text { Goal is elimination (a few cases don't mean } \\
\text { failure) }\end{array}$ & Goal is $100 \%$ eradication \\
\hline
\end{tabular}

COVID-19 highlights how the smallest of 'unwanted organisms' (a virus) can influence states' leaders to quarantine the globe in a manner reminiscent of national animal biosecurity management (for M. bovis). ${ }^{104}$ Biosecurity practices being used to deal with infectious human diseases is a new phenomenon for New Zealanders; we are used to biosecurity measures being taken to quarantine animals and plants, but we are not experienced with these being applied to ourselves. The lessons learned from the M. bovis biosecurity response have been partially credited for New Zealand's swift and successful elimination of COVID-19. ${ }^{105}$ In turn, the learning gained from managing COVID-19 and its many impacts will help us to reconsider how animal biosecurity is understood 
and performed. As an infectious disease of pandemic proportions, COVID-19 demands that we reconceptualise our relationships with the more than social world, including farmed and wild animals. ${ }^{106}$

Figure 2: Biosecurity posters for humans and animals: The 2-metre rule.
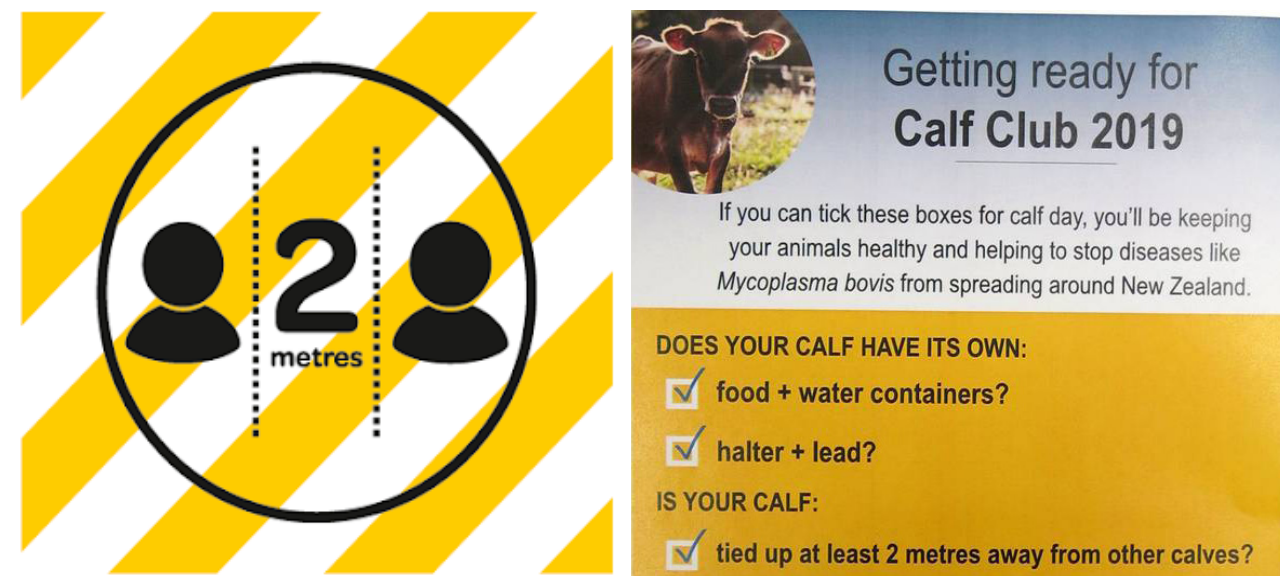

\section{Keep a 2-metre distance from others}

Outside of your home or when you are sick, keep 2 metres away from all other people, where possible. Do not shake hands, kiss helloor hong.

Find out more at Covid19.govt.nz Unite
against
COVID-19

NewZealend Government

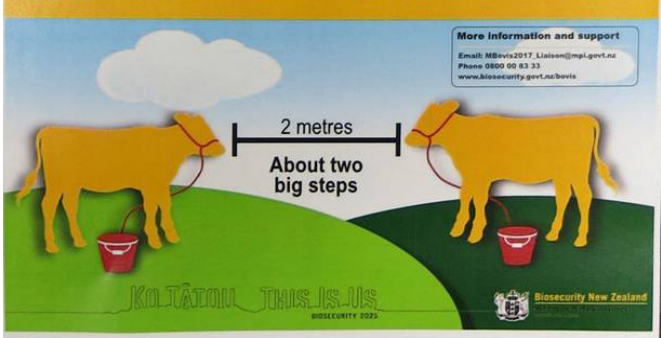

Post-COVID-19, the world must re-evaluate current understandings of human and animal bodies, borders and boundaries, movements and freedoms, economies and environs, and health and risk. In coming years, risks to human health will likely be more prevalent in assessments of the biological safety of animals, farming systems and primary products. ${ }^{107}$ New Zealand's economic security rests heavily on maintaining a premium biosecurity status, and this includes protecting human and animal health for its citizens and reassuring its trading partners of the safety of its food. New Zealand could well be in the position of advising other countries about good biosecurity practices in all of their forms post-COVID-19. ${ }^{108}$ 


\section{Concluding remarks}

The social and economic fallout from New Zealand's nationwide lockdown and other countries' border and biosecurity responses is still being realised in the context of an ongoing global pandemic. It is clear that New Zealand's biological security must now be understood in the context of human health, border closures and supply-chain insecurities. We have seen for the first time in many generations the direct relationship between global health and the global economy, and there are many questions and issues arising for debate and resolution post-pandemic.

This article opened with a reference to the Security System Handbook, which expressly refers to biosecurity incursions and pandemics as matters of national security, but which appears to treat them as separate security categories. Yet, there is too much overlap in a more than social world to treat them separately. Zoonotic diseases capable of reaching pandemic proportions pose an ever-present threat to national security, and COVID-19's impact on New Zealand can be seen particularly starkly in another objective set out in the Security System Handbook: "[s]ustaining economic prosperity."109

It remains to be seen how New Zealand's public health and biosecurity systems will cope with another global zoonotic disease outbreak. This time around we are climbing a steep learning curve involving the biosecurity management of humans. Next time, we may need to apply that learning to, for example - a localised outbreak of dengue fever in Auckland or malaria in the Hokianga. From insects to animals and humans, biosecurity is concerned with the management of emerging life, and the goal is biological security in all of the ways that matter in human societies.

Castree et al. (2020) argue that there are critical normative questions arising from COVID-19 about global inequities in poverty and human health, food safety and wild food sources, the preparedness of public health systems and the ease with which the (comparatively) wealthy travel around the world. ${ }^{110}$ Closer to home, a key issue is how New Zealand will continue to ensure safe and sanitary exports of animal products in a world where the word 'zoonotic' has become a common (and frightening) term. What about immigration decision-making? Perhaps the term 'belonging' will take on a new meaning framed by epidemiological concerns. There could certainly be unforeseen environmental benefits in the current decline of people movements globally, and some are even being seen in the short to medium-term. ${ }^{111}$ There will be biosecurity opportunities in this ongoing crisis, too, and normatively speaking we should take advantage of them. ${ }^{112}$ The overarching question for New Zealand is how our biosecurity story can integrate the goal of human health as it evolves to meet the future challenges inherent in a world that has always been and will always be more than social. 
1 The term 'black swan' event was coined by Nassim Nicholas Taleb to describe unpredictable and rare events that create disproportionately severe impacts on humans, economies or environments. See Nassim Nicolas Taleb, The Black Swan (New York: Random House, 2007). The New Yorker magazine recently interviewed Taleb about COVID-19, and during the interview Taleb said that COVID-19 was not a black swan event, because the outbreak was predictable and should have been expected. Bernard Avishai, "The Pandemic Isn't a Black Swan but a Portent of a More Fragile Global System", The New Yorker, 21 April 2020, https://www.newyorker.com/news/daily-comment/the-pandemic-isnt-a-black-swan-but-a-portentof-a-more-fragile-global-system.

2 The World Health Organisation website on pandemic planning and preparedness shows, for example, that the Organisation has been concerned about emerging global influenza pandemics since the 1950s. See the World Health Organisation,

https://www.who.int/influenza/preparedness/pandemic/en/. In addition, One Health is a World Health Organisation initiative that takes a multidisciplinary approach to the preparation for and management of zoonotic diseases. See One Health, https://www.who.int/news-room/q-a-detail/one-health.

3 See above, and the FAO's Biosecurity Toolkit (Rome: Food and Agriculture Organisation of the United Nations, 2007), http://www.fao.org/3/a1140e/a1140e00.htm. The Biosecurity Toolkit explains the integrated and coordinated biosecurity approach to managing zoonotic diseases at an international level.

4 Kezia Barker. "Flexible Boundaries in Biosecurity: Accommodating Gorse in Aotearoa New Zealand." Environment and Planning A, 40, no. 7 (2008): 1598-1614.

5 See for example the 'Five Strategic Directions' set out in the policy document titled Biosecurity 2025: Direction Statement for New Zealand's Biosecurity System (Wellington: Ministry for Primary Industries, 2016), https:/www.mpi.govt.nz/dmsdocument/14857-biosecurity-2025-direction-statement-for-new-zealands-biosecurity-system.

6 The New Zealand Government, last modified 23 July 2020, .https:/covid19.govt.nz/updates-and-resources/posters/.

7 The Ministry of Health's COVID-19 website provides resources for community education, such as 'stay home' and 'clean and disinfect' posters. These are biosecurity messages, but they are targeting human health for the purpose of eliminating a disease of pandemic proportions. See Ministry of Health, last updated 27 July 2020, https://www.health.govt.nz/our-work/diseases-and-conditions/covid-19-novel-coronavirus. There has been no community messaging from the Ministry of Health or the Ministry for Primary Industries about zoonotic disease spread, good animal husbandry or hygiene practices, biosecurity for hunters or animal-human relations. Perhaps the reason is because the outbreak has already occurred, but it will be interesting to see if there are proactive communications post-COVID-19 about the ever-present risk of zoonotic diseases.

8 The global influenza pandemic of 1918 killed an estimated 50 million people, including 9,000 in New Zealand. See https://www.cdc.gov/flu/pandemic-resources/1918-pandemic-h1n1.html and https:// www.parliament.nz/en/get-involved/features/centenary-of-the-1918-flu-pandemic/. See also John Moremon, "Opinion: History's Pandemics Lost on the Young." Massey University, last updated 20 March 2020, https://www.massey.ac.nz/about-massey/news/article.cfm?mnarticle uuid=FBE1EE23-F6BA4619-89E5-EFA5B81C65BC.

9 Ibid.

10 Information about the high-profile whey protein concentrate incident can be found here: https:// www.mpi.govt.nz/news-and-resources/information-releases/whey-protein-concentrate-contamination-incident/. New Zealand's measles epidemic of 2019 was discussed by the media and by human health professionals as a human disease, though measles is actually a disease with zoonotic origins (Jonathan Ball, "Could Relatives of Measles Virus Jump from Animals to Us?", 1 January 2020, https://www.bbc. com/news/science-environment-50839868.

11 The WPC80 Incident: Causes and Responses. Government Inquiry into the Whey Protein Concentrate Contamination Incident (Wellington: Department of Internal Affairs, November 2014), https:// www.dia.govt.nz/vwluResources/Government-Whey-Inquiry-Report-November-2014/\$file/Government-Whey-Inquiry-Report-November-2014.PDF.

12 National Security System Handbook (Wellington: Department of the Prime Minister and Cabinet, 2016), p. 7.

13 New Zealand Influenza Pandemic Plan: A Framework for Action (Wellington: Ministry of Health, 2017). See also the Memorandum of Understanding on Biosecurity Activities between Ministry of Agriculture and Forestry and Department of Conservation, Ministry of Fisheries, 
and Ministry of Health (Wellington, Ministry of Agriculture and Forestry, 2006), www.biosecurity.govt.nz/files/biosec/policylaws/mou/biosecurity-mou.pdf.

14 New Zealand Influenza Pandemic Plan: A Framework for Action (Wellington: Ministry of Health, 2017). Retrieved from https://www.health.govt.nz/system/files/documents/publications/influenza-pandemic-plan-framework-action-2nd-edn-aug17.pdf.

15 Zoonotic diseases (or zoonoses) are diseases that spread from animals to humans. Some zoonotic diseases can spread between animal species before transferring to the human population, and some can then spread from human to human - such as COVID-19. For more information see the Centre for Disease Control and Prevention, last reviewed 14 July 2017, https://www.cdc.gov/onehealth/basics/zoonotic-diseases.html.

16 Bernard Avishai, “The Pandemic Isn't a Black Swan but a Portent of a More Fragile Global System", The New Yorker, 21 April 2020, https://www.newyorker.com/news/daily-comment/the-pandemicisnt-a-black-swan-but-a-portent-of-a-more-fragile-global-system.

17 Andrew Donaldson. "Biosecurity After the Event: Risk Politics and Animal Disease." Environment and Planning A: Economy and Space, 40, no. 7 (2008): 1552-1567.

18 See for example: Henry Buller. "Safe from the Wolf: Biosecurity, Biodiversity, and Competing Philosophies of Nature." Environment and Planning A: Economy and Space, 40, no. 7 (2008): 15831597. Andrew Dobson, Kezia Barker, \& Sarah Taylor, eds. Biosecurity: The Socio-politics of Invasive Species and Infectious Diseases. London: Routledge, 2013. Steve Hinchliffe and Nick Bingham. "Securing Life: The Emerging Practices of Biosecurity." Environment and Planning A: Economy and Space, 40, no. 7 (2008): 1534-1551.

19 Nigel Clark. "Mobile Life: Biosecurity Practices and Insect Globalization. Science as Culture, 22, no. 1 (2013):16-37, p. 18

20 Andrew Donaldson. "Governing Biosecurity." In Biosecurity: The Socio-politics of Invasive Species and Infectious Diseases, edited by Andrew Dobson, Kezia Barker and Sarah Taylor. London: Routledge, 2013, pp. 61-74.

21 Steve Hinchliffe and Nick Bingham. "Securing Life: The Emerging Practices of Biosecurity." Environment and Planning A: Economy and Space, 40, no. 7 (2008): 1534-1551, p. 1542.

22 Stephen J. Collier, Andrew Lakoff and Paul Rabinow. "Biosecurity: Towards an Anthropology of the Contemporary." Anthropology Today, 20, no. 5 (2004): 3-7, p. 3.

23 Referring to the 2015 fruit fly biosecurity response based in Grey Lynn, Auckland. For more information, see the Ministry for Primary Industries, last reviewed 11 June 2020, https://www.biosecurity. govt.nz/protection-and-response/responding/alerts/queensland-fruit-fly/eradication-of-queensland-fruitfly/.

24 Bruce Braun. "Thinking the City through SARS: Bodies, Topologies, Politics." In Networked Disease: Emerging Infections in the Global City, edited by S. Harris Ali and Roger Keil. Oxford: Wiley-Blackwell, 2008, pp. 250-266, p. 258.

25 Ibid, pp. 250-266.

26 Kezia Barker. "Introduction: Interrogating Bio-insecurities." In Biosecurity: The Socio-politics of Invasive Species and Infectious Diseases, edited by Andrew Dobson, Kezia Barker and Sarah Taylor. London: Routledge, 2013, pp. 3-28.

27 Centre for Disease Control and Prevention, last reviewed 14 July 2017, https://www.cdc.gov/onehealth/basics/zoonotic-diseases.html.

28 S. Harris Ali and Roger Keil, eds. Networked Disease: Emerging Infections in the Global City. Oxford: Wiley-Blackwell, 2008.

29 Braun, 2008.

30 Steve Hinchliffe and Kim J. Ward. "Geographies of Folded Life: How Immunity Reframes Biosecurity." Geoforum, 53 (2014): 136-144.

31 Steve Hinchliffe, John Allen, Stephanie Lavau, Nick Bingham and Simon Carter. "Biosecurity and the Topologies of Infected Life: From Borderlines to Borderlands." Transactions of the Institute of British Geographers, 38, no. 4 (2013): 531-543.

32 Hinchliffe and Ward, 2014, p. 143.

33 Steve Hinchliffe, John Allen, Stephanie Lavau, Nick Bingham and Simon Carter. "Biosecurity and the Topologies of Infected Life: From Borderlines to Borderlands." Transactions of the Institute of British Geographers, 38, no. 4 (2013): 531-543. 
34 This word is used in the way that Michel Callon uses it, which is to allow an actor or element of a network (such as a virus or bacterium) to show itself, as opposed to overlaying preconceived ideas about how that actor or element performs in the world. See Michel Callon. "Some Elements of a Sociology of Translation: Domestication of the Scallops and the Fisherman of St Brieuc Bay." In Power, Action and Belief: A New Sociology of Knowledge?, edited by John Law. London: Routledge \& Kegan Paul, 1986, pp. 196-233.

35 Steve Hinchliffe. "The Insecurity of Biosecurity: Remaking emerging infectious diseases." In Biosecurity: The Socio-politics of Invasive Species and Infectious Diseases, edited by Andrew Dobson, Kezia Barker and Sarah Taylor. London: Routledge, 2013, pp. 199-214. See also Braun, 2008.

36 Braun, pp. 250-266.

37 For an interesting discussion on biosecurity networks, see Steve Hinchliffe and Nick Bingham.

"People, Animals, and Biosecurity in and through Cities." In Networked Disease: Emerging Infections in the Global City, edited by S. Harris Ali and Roger Keil. Oxford: Wiley-Blackwell, 2008, pp. 214-228.

38 Ibid.

39 Braun, 2008.

40 See generally the Ministry for Primary Industries' webpage on mycoplasma bovis for the types of entities involved with the incursion and biosecurity response. Ministry for Primary Industries, last reviewed 15 July 2020, https://www.biosecurity.govt.nz/protection-and-response/mycoplasma-bovis/.

41 Braun, 2008.

42 Hinchliffe, 2013.

43 Clark, 2013.

44 Braun, 2008, p. 257.

45 Ibid.

46 Kezia Barker, 2013.

47 Hinchliffe, 2013, p. 210.

48 Biosecurity control areas (BCAs) are legally defined areas at ports and airports that allow New Zealand to exercise biosecurity powers, see section 2 of the Biosecurity Act 1993 for the statutory definition. 49 There has been recent international discussion about the possibility of 'immunity passports' postCOVID-19. See for example the WHO's Scientific Brief, 24 April 2020, https://www.who.int/publications/i/item/immunity-passports-in-the-context-of-covid-19.

50 Ministry for Primary Industries, Biosecurity 2025 Direction Statement for New Zealand's Biosecurity System, (Wellington: Ministry for Primary Industries, 2016), p. 4, https://www.mpi.govt.nz/dmsdocument/14857-biosecurity-2025-direction-statement-for-new-zealands-biosecurity-system.

51 Ministry for Primary Industries, last reviewed 2 July 2020, https://www.mpi.govt.nz/law-and-policy/ legal-overviews/biosecurity/.

52 Ministry for Primary Industries, Biosecurity 2025 Workplan: Strategic Direction 5 Tomorrow's skills and assets (Wellington: Ministry for Primary Industries, 2018), p. 11, http://www.biosecurity2025.nz/ assets/Resources/8f83c1a57b/Work-plan-Strategic-Direction-5.pdf.

53 Ministry for Primary Industries, Tiakina Aotearoa/Protect New Zealand: The Biosecurity Strategy for New Zealand (Wellington: Ministry for Primary Industries, 2003), p. 5, https://www.mpi.govt.nz/ dmsdocument/7152/direct.

54 Vaughan Higgins and Jacqui Dibden. "Biosecurity, Trade Liberalisation, and the (Anti)politics of Risk Analysis: The Australia-New Zealand Apples Dispute." Environment and Planning A, 43, no. 2 (2011): 393-409.

55 Christine Trampusch. "Protectionism, Obviously, is not Dead: A Case Study on New Zealand's Biosecurity Policy and the Causes-of-Effects of Economic Interests." Australian Journal of Political Science, 49, no. 2 (2014): 206-220.

56 Ibid, p. 214.

57 David Norton, Laura Young, Andrea Byrom, Bruce Clarkson, Phil Lyver, Matt McGlone and Nick Waipara. "How Do We Restore New Zealand's Biological Heritage by 2050 ?" Ecological Management \& Restoration, 17, no. 3 (2016): 170-179. Ministry for Primary Industries, 2016. Department of Conservation, New Zealand Biodiversity Action Plan, (Wellington: Department of Conservation, 2016). In addition, see Ministry for Primary Industries, "Ko Tatou/This is Us", https://www.thisisus.nz/. 
58 Ministry for Primary Industries, Situation and Outlook for Primary Industries, (Wellington: Ministry for Primary Industries, December 2019), https://www.mpi.govt.nz/dmsdocument/38930-situation-and-outlook-for-primary-industries-sopi-december-2019. See also Organisation for Economic Co-operation and Development, OECD Environmental Performance Reviews: New Zealand, (Paris: Secretary-General of the OECD, 2017), https://www.oecd-ilibrary.org/docserver/9789264268203-en.pd-

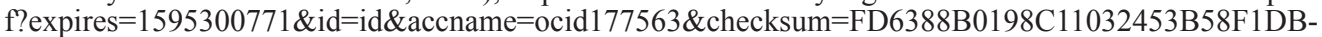
FC546.

59 Ministry for Primary Industries, December 2019.

60 Ibid.

61 Ministry for Primary Industries, Economic Update for the Primary Industries, (Wellington: Ministry for Primary Industries, June 2020), https://www.mpi.govt.nz/dmsdocument/40808/direct.

62 Ibid.

63 Ibid.

64 Ibid.

65 Department of Conservation, 2016. Norton et. al, 2016.

66 Norton et. al, 2016.

67 Radio New Zealand, “Air New Zealand Job Cuts Rushed, Poorly Planned - Union”, 10 April 2020, https:/www.rnz.co.nz/news/business/413947/air-new-zealand-job-cuts-rushed-poorly-planned-union. Amanda Cropp, “Tourism Says Many Jobs Will Go Despite \$400M Budget Rescue Package”, Stuff, 14 May 2020, https:/www.stuff.co.nz/business/121510219/tourism-says-many-jobs-will-go-despite-400mbudget-rescue-package?rm=a.

68 Jason Walls, "Covid-19 Coronavirus: Govt Spending \$4.4 Billion Higher than Forecast as Deficits Loom”, NZ Herald, 8 May 2020, https://www.nzherald.co.nz/business/news/article.cfm?c_id=3\&objectid=12330506.

69 Trampusch, 2014.

70 Max Towle, "How the Climate is Benefiting from COVID-19", Radio New Zealand, 24 March 2020, https:/www.rnz.co.nz/news/national/412526/how-the-climate-is-benefiting-from-covid-19. For an alternative view about COVID-19's impact on the environment, see National Geographic, "Why COVID-19 Will End Up Harming the Environment", 18 June 2020, https:/www.nationalgeographic. com/science/2020/06/why-covid-19-will-end-up-harming-the-environment/.

71 Mark McNeill, Tracy Payne and Denise Bewsell. "Tourists as Vectors of Potential Invasive Alien Species and a Strategy to Reduce Risk." Re-creating Tourism: New Zealand Tourism and Hospitality Research Conference (December 2008). Retrieved from https://www.researchgate.net/publication/303698468_Tourists_as_vectors_of_potential_invasive_alien_species_and_a_strategy_to_reduce_ risk. See also Ministry for Primary Industries, $201 \overline{6}$.

72 Ministry of Business, Innovation and Employment, https://www.mbie.govt.nz/immigration-and-tourism/tourism/tourism-funding/international-visitor-conservation-and-tourism-levy/.

73 Jacques Tassin and Christian Kull. "Facing the Broader Dimensions of Biological Invasions." Land Use Policy, 42 (2015): 165-169, p. 166.

74 See Waitangi Tribunal, Ko Aotearoa Tēnei: Report on the WAI262 Claim (Wellington: Ministry of Justice, 2011), https://waitangitribunal.govt.nz/news/ko-aotearoa-tenei-report-on-the-wai-262-claim-released/.

75 Mark Williamson and Alastair Fitter. “The Varying Success of Invaders.” Ecology, 77, no. 6 (1996): 1661 - 1666. The 'tens-rule' was established in the northern hemisphere and should be interpreted cautiously, although it is instructive in demonstrating that not all imported species are problematic to local biodiversity.

76 Lesley Head and Pat Muir. "Nativeness, Invasiveness, and Nation in Australian Plants." Geographical Review, 94, no. 2 (2004): 199-217.

77 Franklin Ginn. "Extension, Subversion, Containment: Eco-nationalism and (Post)colonial Nature in Aotearoa New Zealand.” Trans Inst Br Geogr, 33 (2008): 335-353.

78 Elisha Foon, "Spike in Racism During Pandemic, Human Rights Commission Reports", Radio New Zealand, 3 May 2020, https://www.rnz.co.nz/news/national/415691/spike-in-racism-during-pandemichuman-rights-commission-reports. Charlie Dreaver, 'National MP's Comments 'Disgraceful, Racist' Megan Woods", Radio New Zealand, 2 July 2020, https://www.rnz.co.nz/news/political/420379/national-mp-s-comments-disgraceful-racist-megan-woods. 
79 Centres for Disease Control and Prevention, last reviewed 19 August 2014, https://www.cdc.gov/flu/ swineflu/people-raise-pigs-flu.htm. Centres for Disease Control and Prevention, last reviewed 6 February 2017, https://www.cdc.gov/flu/avianflu/avian-in-birds.htm.

80 New Zealand is a signatory to the Convention on the Conservation on Migratory Species of Wild Animals, also known as the 'Bonn Convention'. Retrieved from https://www.cms.int/.

81 New Zealand Influenza Pandemic Plan: A Framework for Action (Wellington: Ministry of Health, 2017). Retrieved from https:/www.health.govt.nz/system/files/documents/publications/influenza-pandemic-plan-framework-action-2nd-edn-aug17.pdf.

82 Ted Regencia, “600,000 Dead as Coronavirus Rebounds Around the World: Live”, Aljazeera, 20 July 2020, https://www.aljazeera.com/news/2020/07/worldwide-coronavirus-death-toll-nears-600000live-updates-200718232028622.html, dated accessed 22 July 2020. Ministry of Health, last updated 21 July 2020, https://www.health.govt.nz/our-work/diseases-and-conditions/covid-19-novel-coronavirus/ covid-19-current-situation/covid-19-current-cases.

83 Professor Michael Baker, "Coronavirus live Q\&A: Epidemiologist professor Michael Baker on how NZ is tracking”, 28 April 2020, https:/www.stuff.co.nz/national/health/coronavirus/121302681/coronavirus-live-qa-epidemiologist-professor-michael-baker-on-how-nz-is-tracking, date accessed 22 July 2020.

84 Centres for Disease Control and Prevention, last reviewed 20 March 2019, https://www.cdc.gov/ flu/pandemic-resources/1918-pandemic-h1n1.html. New Zealand Parliament, "Centenary of the 1918 Flu Pandemic", 22 November 2018, https:/www.parliament.nz/en/get-involved/features/centenary-of-the-1918-flu-pandemic/.

85 Professor Jonathan Runstadler, "Influenza's Wild Origins in the Animals Around Us", The Conversation, 9 March 2018, https://theconversation.com/influenzas-wild-origins-in-the-animals-around-us-91058, date accessed 22 July 2020.

86 The vast majority of all transmissible diseases in humans have zoonotic origins, including H5N1 and H7N9 (avian flu), H1N1 (swine flu), Severe Acute Respiratory Syndrome, Middle Eastern Respiratory Syndrome, the Ebola Virus Disease and of course COVID-19. See the World Health Organisation, https://www.who.int/zoonoses/en/.

87 World Health Organisation, https://www.who.int/zoonoses/diseases/en/.

88 See for examples of New Zealand's animal biosecurity management, see the Biosecurity New Zealand website, https://www.mpi.govt.nz/protection-and-response/.

89 A phrase coined by Steve Hinchliffe, John Allen, Stephanie Lavau, Nick Bingham and Simon Carter. "Biosecurity and the Topologies of Infected Life: From Borderlines to Borderlands." Transactions of the Institute of British Geographers, 38, no. 4 (2013): 531-543. Absent presences are actions or things that are made invisible or normalised within a narrative, even if they are foundational to its continuation, but they are not made express.

90 Ministry for Primary Industries, December 2019. Department of Conservation, 2016. See also Organisation for Economic Co-operation and Development, 2017.

91 Ibid.

92 Professor Michael Baker, "Why New Zealand Decided to go for Full Elimination of the Coronavirus", New Scientist, 23 June 2020, https:/www.newscientist.com/article/2246858-why-new-zealand-decided-to-go-for-full-elimination-of-the-coronavirus/, date accessed 22 July 2020.

93 Barker, 2008. See also Phillip Hulme, "Covid-19 Proves Better New Zealand Biosecurity Possible", Stuff, 11 May 2020, https:/www.stuff.co.nz/science/121436476/covid19-proves-better-nz-biosecurity-possible, date accessed 22 July 2020.

94 See S. Harris Ali and Roger Keil, 2008.

95 On COVID-19 website there is a drop-down menu listing government response actions, including testing (community surveillance), contact tracing and quarantine. Ministry of Health, last modified 3 July 2020, https://covid19.govt.nz/covid-19/covid-19-all-of-government-response-group/. These types of biosecurity response practices can also be found on the MPI website relating to a range of plant and animal disease incursions. Ministry for Primary Industries, last reviewed 27 June 2019, https://www.biosecurity. govt.nz/protection-and-response/mycoplasma-bovis/what-is-mpi-doing/.

96 An outline of Foucauldian-type disease management epistemologies can be found in Philipp Sarasin. "Vapors, Viruses, Resistance(s): The Trace of Infection in the Work of Michel Foucault." In Networked Disease: Emerging Infections in the Global City, edited by S. Harris Ali and Roger Keil. Oxford: Wiley-Blackwell, 2008, pp. 267-280. 
97 Steven Phillips, M.D., “The Pandemic Winner: Will It be Sweden or New Zealand?”, The Hill, https://thehill.com/opinion/international/495823-the-pandemic-winner-will-it-be-sweden-or-new-zealand, date accessed 22 July 2020.

98 New Zealand Herald, "Covid 19 Coronavirus: Swedish Expert says NZ Faces Years of Quarantine for Arrivals", 9 May 2020, https:/www.nzherald.co.nz/world/news/article.cfm?c_id=2\&objectid $=12330725$.

99 Tim Newman, "Government Announces Changes to Biosecurity and Animal Tracing”, Stuff, 19 July 2019, https://www.stuff.co.nz/business/farming/114357084/government-announces-changes-to-biosecurity-and-animal-tracing, date accessed 13 May 2020.

100 Statistics New Zealand, https://www.stats.govt.nz/indicators/livestock-numbers, last updated 18 April 2019.

101 See the Report of the Mycoplasma Bovis Technical Advisory Group (TAG) in Response to the

Terms of Reference (June 2019). Wellington: Ministry for Primary Industries, October 2019. Retrieved from https://www.biosecurity.govt.nz/dmsdocument/37754-report-of-the-mycoplasma-bovis-technicaladvisory-group-tag-in-response-to-the-terms-of-reference-june-2019-18-october-2019.

102 At present, the potential for humans to obtain immunity to COVID-19 through infection is likely but the extent and term of any immunity is unclear. See discussion of Professor Michael Baker, "Why New Zealand Decided to go for Full Elimination of the Coronavirus", New Scientist, 23 June 2020, https:// www.newscientist.com/article/2246858-why-new-zealand-decided-to-go-for-full-elimination-of-thecoronavirus/, date accessed 22 July 2020.

103 The data for this comparative analysis came from information collected from Ministry for Primary Industries, DairyNZ Limited, World Health Organisation and reputable media websites, such as Radio New Zealand. The majority of the information used in this comparison is now common knowledge. 104 As a relevant aside, the term 'unwanted organism' is defined by s 2 of the Biosecurity Act 1993 as an organism having the potential to cause unwanted harm to natural/physical resources or human health. 105 Bonnie Flaws, “Going 'Hard and Early' on M. Bovis Paid Dividends: PM”, Stuff, 26 May 2020, https://www.stuff.co.nz/business/farming/121627591/going-hard-and-early-on-m-bovis-paid-dividendspm, date accessed 18 July 2020.

106 See Noel Castree, Louise Amoore, Alex Hughes, Nina Laurie, David Manley and Susan Parnell. "Boundless Contamination and Progress in Geography." Progress in Human Geography, 44, no. 3 (2020): 411-414. The authors observe that COVID-19 "has compressed, in a confronting way, the sort of massive questions and challenges represented by humanity's long-term transformation of the Earth" ( $p$. 413).

107 A small indicator, but there is a post-COVID-19 increase in New Zealand's exports for fruit (Ministry for Primary Industries, 2020).

108 Better Border Biosecurity, "Facing Covid -19 and Future Pandemics. What Can We Learn From New Zealand's Biosecurity System?”, 15 June 2020, https://www.scoop.co.nz/stories/PO2006/S00132/ facing-covid-19-and-future-pandemics-what-can-we-learn-from-new-zealands-biosecurity-system.htm, date accessed 19 July 2020.

109 National Security System Handbook (Wellington: Department of the Prime Minister and Cabinet, 2016), p. 8.

110 Noel Castree, Louise Amoore, Alex Hughes, Nina Laurie, David Manley, Susan Parnell. "Boundless Contamination and Progress in Geography." Progress in Human Geography, 44, no. 3 (2020): 411-414. 111 Max Towle, "How the Climate is Benefiting from COVID-19", Radio New Zealand, 24 March 2020, https://www.rnz.co.nz/news/national/412526/how-the-climate-is-benefiting-from-covid-19.

112 One example of a biosecurity opportunity is evident from Hon. Grant Robertson's Budget Speech 2020, 14 May 2020, in which money has been allocated to (among other things) employing people to remove wild conifers from conservation land. Retrieved from https://treasury.govt.nz/sites/default/ files/2020-05/b20-speech.pdf. 